\title{
Serum 25-hydroxyvitamin D3 levels and vitamin $D$ receptor variants in melanoma patients from the Mediterranean area of Barcelona
}

Zighereda Ogbah*, Laura Visa', Celia Badenas ${ }^{2,3}$, José Ríos $^{4}$, Joan Anton Puig-Butille ${ }^{2,3}$, Nuria Bonifaci ${ }^{5}$, Elisabet Guino ${ }^{5}$, Josep Maria Augé ${ }^{2}$, Isabel Kolm¹, Cristina Carrera', Miquel Ángel Pujana ${ }^{5}$, Josep Malvehy ${ }^{1,2,3}$ and Susana Puig ${ }^{1,2,3^{*}}$

\begin{abstract}
Background: Serum 25-hydroxyvitamin D3 (Vitamin D) insufficiency and single-nucleotide polymorphisms (SNPs) on its receptor, Vitamin D receptor $(V D R)$, have been reported to be involved in melanoma susceptibility in populations mostly from northern countries.

Objective: To investigate 25-hydroxyvitamin D3 levels and VDR SNPs in melanoma patients from sunny area of Barcelona, two studies were carried out. The first study evaluated the levels of Vitamin D at time of melanoma diagnosis and the second one analyzed the association between VDR genetic variants and risk of having a high nevus number, the strongest phenotypic risk factor for melanoma.

Methods: The levels of 25-hydroxyvitamin D3 in 81 melanoma patients at diagnosis were measured. In a second group of melanoma patients, including 150 with low and 113 with high nevus number, 11 VDR SNPs were analyzed for their association with nevus number.

Results: In the first study, $68 \%$ of patients had insufficient levels of 25 -hydroxyvitamin D3 ( $225 \mathrm{ng} / \mathrm{ml})$. Autumnwinter months and fair phototype were associated with 25-hydroxyvitamin D3 insufficiency; after multivariate analysis, season of sampling remained the only independent predictor of 25-hydroxyvitamin D3 levels. In the second study, VDR variant rs2189480 $(P=0.006)$ was associated with risk of high nevus number whereas rs2239179 $(P=0.044)$ and rs7975128 $(P=0.0005)$ were protective against high nevus number. After Bonferroni adjustment only rs7975128 remained significant. In stratified analysis, SNP rs7975128 was found protective against multiple melanomas $(P=0.021)$.

Conclusion: This study showed that even in Barcelona, a sunny Mediterranean area, 25-hydroxyvitamin D3 levels were sub-optimal in the majority of melanoma patients at diagnosis. The involvement of VDR in nevi and, in turn, in melanoma susceptibility has also been suggested. Larger studies are needed to confirm our findings.
\end{abstract}

Keywords: Vitamin D, VDR, SNP, Melanoma

\footnotetext{
* Correspondence: zigheog@gmail.com; spuig@clinic.ub.es

${ }^{1}$ Melanoma Unit, Department of Dermatology Hospital Clínic de Barcelona,

IDIBAPS, Barcelona University, Barcelona, Spain

${ }^{2}$ Melanoma Unit, Biochemistry and Molecular Genetics Service, Hospital Clínic

de Barcelona, IDIBAPS, Barcelona University, Barcelona, Spain

Full list of author information is available at the end of the article
} 


\section{Background}

Serum 25-hydroxyvitamin D3 (Vitamin D) is a hormone classically known for its regulation of bone and calcium metabolism. In recent years interest in 25-hydroxyvitamin D3 has grown as evidence has shown it to play a role in cancer susceptibility and outcome, postulated to be related to its anti-proliferative pro-apoptotic and pro-differentiation properties [1,2]. Suboptimal levels of 25-hydroxyvitamin D3 have been shown to be associated with increased risk of several cancers including melanoma $[3,4]$. Patients diagnosed with melanoma had suboptimal levels of 25-hydroxyvitamin D3 in the North of England within a few months of diagnosis, especially in winter months [5] and a reduced level of 25-hydroxyvitamin D3 was associated with thicker melanomas, poorer outcome [5] and aggressive melanoma [6]. There are no reports of 25-hydroxyvitamin D3 levels in melanoma patients living in sunny Mediterranean countries and we therefore herein report a small study in melanoma patients from Barcelona.

Sunburn and intermittent sun exposure are the most important environmental risk factors for melanoma [7] but sun exposure is also the main source for 25hydroxyvitamin D3 photosynthesis. 25-hydroxyvitamin D3 derives from cholesterol metabolites in skin after exposure to ultraviolet $B$ radiation (UVB) [8]. The skin exposure to UVB induces the photolytic conversion of 7-dehydrocholesterol (7-DHC) to previtamin $\mathrm{D}$ and from there to vitamin D3. The metabolic activation of vitamin D3 requires two hydroxylation steps [9]. The first hydroxylation occurs in the liver where vitamin D3 is converted in 25-hydroxyvitamin D3, the major circulating metabolite of vitamin $\mathrm{D}_{3}$. The second hydroxylation transformed in the kidney the 25-hydroxyvitamin D3 in 1,25-dihydroxyvitamin D3. While circulating 1,25dihydroxyvitamin D3 levels mainly reflect the synthesis of 1,25-dihydroxyvitamin D3 in the kidney, 25hydroxyvitamin D3 serum levels are a good parameter of whole body vitamin D status and for this reason is the metabolite most measured for the classification of vitamin D status [10]. In vitro, 25-hydroxyvitamin D3 has been shown to inhibit the growth of normal melanocytes and melanocytes derived from melanoma [11,12]. The 25-hydroxyvitamin D3 mediates its biological effects by binding to its specific nuclear receptor, Vitamin D Receptor (VDR) [13].

The VDR gene, located on chromosome 12q13.11, has more than 200 single-nucleotide polymorphisms (SNPs) [14] but only a few SNPs, considered to be functional [15], have been studied for their potential associations with melanoma susceptibility [16-21]. Meta-analysis of all reports published by 2009 supported the association between $V D R$ functional SNPs BsmI (rs1544410) and FokI (rs2228570) and melanoma risk [22,23]. More recently a large SNP study showed that common inherited variants at $V D R$ influence melanoma risk [24], providing further evidence supporting a role for 25hydroxyvitamin D3 in melanoma susceptibility.

Common acquired nevi are melanocytes in proliferation and high nevus number represents the strongest phenotypic risk factor for melanoma development [25,26]. Genome-wide association studies have identified common susceptibility genes for melanoma and increased nevus number $[27,28]$.

If $V D R$ SNPs are associated with melanoma risk therefore, elucidating the relationship between $V D R$ variants and nevi is an important step towards understanding the involvement of $V D R$ and, indirectly, of 25-hydroxyvitamin $\mathrm{D} 3$, in melanoma carcinogenesis.

The association between 25-hydroxyvitamin D3 levels and/or inherited variation in $V D R$ and melanoma risk has been studied in few populations, mostly from northern countries such as England, USA, Poland and Germany [4,6,21-23]. Only two reports on $V D R$ variants have been published from southern European countries, specifically Italy and Spain [18,29].

We presented the results of two studies performed in Barcelona melanoma patients. The first study evaluated the levels of 25-hydroxyvitamin D3 at time of melanoma diagnosis and the second one analyzed the association between $V D R$ genetic variants and risk of having a high nevus number.

\section{Methods}

\section{Study design}

Two cohort studies both including Caucasian melanoma patients were carried out. The two studies were mutually exclusive (each patient is present in only one study) and included groups of patients belonging to two different studies. In the first, a retrospective cohort study, 25hydroxyvitamin D3 levels were measured in serum samples stored from melanoma patients at diagnosis for the investigation of biomarkers. In the second, the association between $V D R$ variants and nevus number was evaluated in a second cohort of melanoma patients recruited to a genetic epidemiological study of nevi. Patients were selected according to the total nevus number at the time of melanoma diagnosis and classified into two groups: 150 cases with a low nevus number ( $<50$ nevi) and 113 cases with a high nevus number ( $>100$ nevi). We selected two groups of patients where there would be no possible overlap between them, as $<50$ nevi were closer to the normal nevus number in our population [30] and >100 nevi being a well- documented risk factor for melanoma [26].

Both cohort studies included melanoma patients from the urban area of Barcelona recruited from the Melanoma 
Unit of Hospital Clinic of Barcelona. This is a referral centre for Melanoma in the Catalonia region.

Both studies were approved by the Ethics Committee of the Hospital Clinic of Barcelona and written informed consent was obtained from all participants in the study.

\section{The first set of melanoma patients (25-hydroxyvitamin D3 study)}

The patients had all been diagnosed with melanoma between 2004-2008. Patients were those recruited to the epidemiological study from which serum samples had been cryopreserved in the Biobank of Hospital Clínic and where the blood was collected within a maximum of 3 months after melanoma diagnosis. All patients had localized tumors (stage I and stage II) except one (stage IIIa) which had lymph node micrometastasis. Data on gender, age at melanoma diagnosis, nevus number, Fitzpatrick skin type, eye color, hair color, examined actinic damage, number of melanoma, Breslow thickness, reported solar exposure before 10 years of age, between 10-18 and over 18 years were collected through a questionnaire or extracted by medical records. Participants were asked about weight, height and habits of photoprotection via an interview.

\section{The second set of melanoma patients (VDR polymorphisms study)}

A total of 263 melanoma patients were recruited between 2004-2007. The patients were selected according to the total number of nevi at the time of melanoma diagnosis and classified into two groups: 150 cases with a low nevus number (cases with <50) and 113 cases with a high nevus number (cases with $>100$ ). Total body nevus number has been performed by dermatologists and trained nurses. Data on gender, age at melanoma diagnosis, nevus number, Fitzpatrick skin type, eye color, hair color, examined actinic damage, number of melanoma, reported solar exposure as before 10 years of age, between 10-18 and over 18 years were collected through a questionnaire or extracted by medical records.

\section{5-hydroxyvitamin D3 measurement}

The levels of 25-hydroxyvitamin D3 (ng/ml) were analyzed by a chemiluminescence immunoassay method using the Liaison ${ }^{\circledR}$ kit (DiaSorin, Minnesota, USA) as previously described [31]. This method has a detection limit range from $4 \mathrm{ng} / \mathrm{ml}$ to $150 \mathrm{ng} / \mathrm{ml}$. Insufficient level of 25-hydroxyvitamin D3 was defined as less than $25 \mathrm{ng} / \mathrm{ml}$ (60 nmol/L).

\section{VDR polymorphisms genotyping}

In total, 11 VDR SNPs rs7136534, rs11574027, 11168287, rs2238136, rs3782905, rs2189480, rs2239179, rs11574077, rs11168267 and rs7975128 were analyzed.
All SNPs were selected as having minor allele frequencies $(\mathrm{MAF}) \geq 0.05$ in HapMap (www.hapmap.org) European individuals and at least one independent validation criterion, as established in dbSNP (htpp://www.ncbi.nlm.nih. gov/snp). The SNPs were selected using data from the HapMap project and the Tagger tool [32] with linkage disequilibrium $\mathrm{r}^{2}>0.5$.

Genomic DNA was isolated from peripheral blood samples using the salting-out method. Genotyping was performed with GenomeLab SNPstream genotyping platform (Beckman \& Coulter Inc. Fullerton, CA) and its accompanying SNPstream software, according to the manufacturer's protocols. Primers were designed using Autoprimer (http://www.autoprimer.com). The design of the primers failed in the presence of adjacent SNPs or of repeat sequence which can interfere with primers annealing. If a selected SNP failed assay primer design, if possible, an alternative tagging SNP in complete LD was chosen. Two SNPs, FokI (rs2228570) and BsmI (rs1544410), failed primer design. By HapMap, BsmI was replaced with rs7975128 as in strong $\mathrm{LD}(\mathrm{r} 2=1)$ in the Caucasian population while no other variants in LD were found for FokI. Samples and SNPs with call rates below 90\% were excluded from the analysis. Failed genotypes were not repeated. As quality controls, 10\% of samples were added as duplicates so that concordance between genotype calls could be assessed. The genotyping assays were performed at the LIMM (Leeds) genotyping facilities.

\section{Statistical method}

Quantitative variables were described using median and interquartile range (percentiles $25^{\text {th }}$ and $75^{\text {th }}$ ). Inferential analyses for these variables were performed by $U$ Mann-Whitney or Wilcoxon test for unpaired data. Qualitative variables were tabulated by absolute frequencies and percentages and evaluated using $\chi^{2}$ test or Fisher's exact test where appropriate.

\section{5-hydroxyvitamin D3}

The analysis was performed using SPSS v15.0 (SPSS Inc., Chicago IL). The level of statistical significance was set at $P<0.05$. Logistic regression was used to estimate Odds Ratio (OR) and 95\% Confidence Interval (CI) for association between 25-hydroxyvitamin D3 levels $(<25 \mathrm{ng} / \mathrm{ml})$ and gender, age diagnosis of melanoma $(<55 />55)$, BMI (normal weight/overweight/obese), Fitzpatrick skin type (dark/fair), eye color (dark/light), hair color (dark/light), actinic damage (no/yes); habits of photoprotection (usually/never), solar exposure (none to mild, that is under 50 hour per year $(\mathrm{h} / \mathrm{y})$ or moderate to severe that is more than $50(\mathrm{~h} / \mathrm{y}))$ before 10 years of age, between 10-18 and over 18 years, number of melanoma (single/multiple) and Breslow $(<0.75 \mathrm{~mm} / 0.75$ - 
$1 \mathrm{~mm} />1 \mathrm{~mm})$. For the purpose of the analysis, Breslow thickness was also analyzed as a continuous variable. The lineal trend of association between 25-hydroxyvitamin D3 levels and Breslow thickness was evaluated by Spearman correlation. In this cohort, cases with an intermediate nevus number between 51 and 99 (51-99) were present; nevus number variable included three groups ( $\leq 50$ nevi), (51-99) and ( $\geq 100$ nevi).

To test the effect of the season on blood sampling as an independent factor, a multivariate approach was performed adjusting by phototype and gender.

\section{VDR polymorphisms}

Statistical analyses were performed using SNPassoc package in $\mathrm{R}$ (version 2.10.1) [33]. Departure from Hardy-Weinberg equilibrium (HWE) for each SNP was assessed by $\chi^{2}$ test. Being a study including only cases, SNPs found outside HWE were analyzed because HWE could be informative for SNPs that confer risk rather than genotyping error. To measure the association between $V D R$ variant alleles and risk for increased number of nevi, cases with less than 50 nevi were compared with cases with more than 100 nevi, where cases $<50$ were considered as the referent group.

The association between genotype and nevus number was estimated using logistic regression and analyzed under co-dominant, dominant, recessive and log-additive models. Significance was defined as $P<0.05$. The best inheritance model was selected using the Akaike criteria. The reported ORs and 95\% CI were adjusted for age and gender. Significant associations between SNPs and nevus number were also tested by the Bonferroni test. To control confounder variables, regression analysis was repeated adjusting for whether there was a single or multiple primaries. Logistic regression was also used to estimate the association between polymorphisms and clinical characteristics such as eye color (dark/light), hair color (dark/light), Fitzpatrick skin phototype (dark/fair), actinic damage (no/yes) and number of melanomas (single/multiple). Associations between VDR SNPs and solar exposure (none-mild $<50 \mathrm{~h} / \mathrm{y} /$ severe-moderate $>50 \mathrm{~h} / \mathrm{y}$ ) before 10 , between $10-18$ and over 18 years was evaluated by interaction analysis.

\section{Results}

\section{5-hydroxyvitamin D3}

Medians levels of 25-hydroxyvitamin D3 and the clinical characteristics of patients are shown in Table 1. A total of 81 patients were analyzed, of whom 38 (47\%) were female. For women, the median was $22.8 \mathrm{ng} / \mathrm{ml}$ and for men, $19.59 \mathrm{ng} / \mathrm{ml}(P=0.477)$. The median $\left(25^{\text {th }}-75^{\text {th }}\right.$ percentiles) age at melanoma diagnosis was 55 (36.767.2). It was observed that younger patients ( $<55$ years) had slightly higher levels of 25-hydroxyvitamin D3 (median $22.5 \mathrm{ng} / \mathrm{ml}$ ) than older patients (>55 years) (median $19.7 \mathrm{ng} / \mathrm{ml})(P=0.441)$.

Serum 25-hydroxyvitamin D3 levels varied with the season of venepuncture (Figure 1). The median level of 25-hydroxyvitamin D3 in April to September was $23.6 \mathrm{ng} /$ $\mathrm{ml}$, exceeding the average of the 25-hydroxyvitamin D3 levels in October to March of $17.9 \mathrm{ng} / \mathrm{ml}(P=0.017)$.

It is known that BMI influences 25-hydroxyvitamin D3 levels. The 25-hydroxyvitamin D3 levels were shown to be lower (median $15.7 \mathrm{ng} / \mathrm{ml}$ ) in obese patients with higher BMI $(B M I \geq 30)$ than in overweight patients with BMI between 25-29.9 (median $19.6 \mathrm{ng} / \mathrm{ml}$ ) and in normal weight patients with $\mathrm{BMI} \leq 24.9$ (median $22.9 \mathrm{ng} / \mathrm{ml})(P=0.06)$.

Patients with phototype I/II had lower levels of 25hydroxyvitamin D3 (median $18 \mathrm{ng} / \mathrm{ml}$ ) than patients with phototype III/IV (median $22.9 \mathrm{ng} / \mathrm{ml})(P=0.005)$ in univariate analysis. Those patients who reported moderate/severe solar exposure before 10 years of age ( $\geq 50 \mathrm{~h} / \mathrm{y}$ ) had higher levels of 25-hydroxyvitamin D3 (median $22.5 \mathrm{ng} / \mathrm{ml}$ ) than those with none/mild solar exposure $(<50 \mathrm{~h} / \mathrm{y})$ (median $16.8 \mathrm{ng} / \mathrm{ml})(P=0.019)$.

A higher percentage of patients with fair skin had none/mild solar exposure $(<50 \mathrm{~h} / \mathrm{y})$ than dark-skinned patients in age groups $<10$ years $(35 \%$ vs $12 \% ; P=0.06)$ (unpublished observations). The use of sunscreen was reported in $70 \%$ of patients. Skin type was also related with sunscreen: $62 \%$ of patients with light skin phototype usually used sunscreen compared with $29 \%$ in patients with darker skin phototype $(P=0.023)$ (unpublished observations).

As regards nevus number, patients with $>100$ showed higher 25-hydroxyvitamin D3 levels $(26.3 \mathrm{ng} / \mathrm{ml})$ than patients with $51-99(20.2 \mathrm{ng} / \mathrm{ml})$ or $<50$ nevi $(21.2 \mathrm{ng} /$ $\mathrm{ml})$ but no significant differences were found among the three groups $(P=0.266)$.

Most of our patients (74\%) had melanomas with Breslow thickness $\leq 2 \mathrm{~mm}$ (range from 0.2 to $7.5 \mathrm{~mm}$ ).

Breslow was analyzed both as continuous and categorical variable. No statistically significant differences were found between Breslow thickness and 25-hydroxyvitamin D3 levels ( $\mathrm{r} 2=0.009, P=0.42$ ). The same result was found when examining the association between Vitamin $\mathrm{D}$ levels and Breslow as a categorical variable $(P=0.544)$.

No associations in levels of 25-hydroxyvitamin D3 were detected for actinic damage $(P=0.161)$, eye color $(P=0.777)$, hair color $(P=0.912)$, photoprotection habits before $10(P=0.569)$, between $10-18(P=0.672)$, over 18 years old $(P=0.824)$ and solar exposure between $10-18$ $(P=0.08)$, over 18 years old $(P=0.267)$ and number of melanomas $(P=0.992)$ (Table 1$)$.

25-hydroxyvitamin D3 level was also evaluated as a dichotomous variable. Two categories were defined: appropriate levels $>25 \mathrm{ng} / \mathrm{ml}$ and insufficient levels $\leq 25 \mathrm{ng} / \mathrm{ml}$. The cut off at $25 \mathrm{ng} / \mathrm{ml}$ was chosen as it is the range 
Table 1 Descriptive analysis of characteristics and medians of 25-hydroxyvitamin D3 levels at time of diagnosis in melanoma patients

\begin{tabular}{|c|c|c|c|c|c|}
\hline & Variables & & No patients* & $\begin{array}{l}\text { Vitamin D levels } \\
\mathrm{ng} / \mathrm{ml}\end{array}$ & $P$ \\
\hline \multirow[t]{18}{*}{ Clinical characteristic* } & \multirow[t]{2}{*}{ Age at diagnosis of melanoma (years) } & $<55$ & 40 & $22.5(16.8-33.4)$ & \multirow[t]{2}{*}{0.441} \\
\hline & & $\geq 55$ & 41 & 19.7(16.4- 24) & \\
\hline & \multirow[t]{2}{*}{ Gender } & Male & 43 & 19.5(13.8- 26) & \multirow[t]{2}{*}{0.477} \\
\hline & & Female & 38 & $22.8(17.8-32.6)$ & \\
\hline & \multirow[t]{3}{*}{$\mathrm{BMI}\left(\mathrm{kg} / \mathrm{m}^{2}\right)$} & Normal weight & 24 & $22.9(19.2-31.6)$ & \multirow[t]{3}{*}{0.063} \\
\hline & & Overweight & 24 & 19.6(15.3- 26.3) & \\
\hline & & Obese & 15 & 15.7(11.4- 25.4) & \\
\hline & \multirow[t]{2}{*}{ Fitzpatrick skin type } & Dark & 37 & 22.9(19.4- 32.6) & \multirow[t]{2}{*}{0.005} \\
\hline & & Fair & 44 & 18(15.5- 24.4) & \\
\hline & \multirow[t]{2}{*}{ Hair color } & Dark & 53 & 21.6(16.8- 26.6) & \multirow[t]{2}{*}{0.912} \\
\hline & & Light & 23 & $22.4(16.4-30.6)$ & \\
\hline & \multirow[t]{2}{*}{ Eye color } & Dark & 38 & $20.5(13.2-26.2)$ & \multirow[t]{2}{*}{0.777} \\
\hline & & Light & 37 & $22.2(17.3-32.5)$ & \\
\hline & \multirow[t]{2}{*}{ Actinic damage } & No & 62 & $22(16.6-29.3)$ & \multirow[t]{2}{*}{0.161} \\
\hline & & Yes & 16 & 18.5(16.3- 32.6) & \\
\hline & \multirow[t]{3}{*}{ Nevus Number } & $<50$ & 34 & 21.2(13.7- 29.9) & \multirow[t]{3}{*}{0.266} \\
\hline & & $51-99$ & 17 & $20.2(17.8-24.3)$ & \\
\hline & & $>100$ & 12 & $26.05(19-36.6)$ & \\
\hline \multirow{12}{*}{$\begin{array}{l}\text { Habits of solar exposure } \\
\text { and photoprotection }\end{array}$} & \multirow[t]{2}{*}{ Solar exposure before 10 years old } & None/Mild & 19 & $16.8(12-27.4)$ & \multirow[t]{2}{*}{0.015} \\
\hline & & Severe/Moderate & 59 & $22.5(17.3-30.6)$ & \\
\hline & \multirow[t]{2}{*}{ Solar exposure $10-18$ years old } & None/Mild & 20 & $17.8(14.5-22.5)$ & \multirow[t]{2}{*}{0.08} \\
\hline & & Severe/Moderate & 57 & $22.9(17.3-32.6)$ & \\
\hline & \multirow[t]{2}{*}{ Solar exposure over 18 years old } & None/Mild & 11 & 17.7(16.4- 23.9) & \multirow[t]{2}{*}{0.267} \\
\hline & & Severe/Moderate & 29 & $22.6(16.8-30.2)$ & \\
\hline & \multirow[t]{2}{*}{ Photoprotection before 10 years old } & Usually & 25 & 22.6(17.3- 27.4) & \multirow[t]{2}{*}{0.569} \\
\hline & & Never & 47 & 20.8(15.7- 31.1) & \\
\hline & \multirow[t]{2}{*}{ Photoprotection $10-18$ years old } & Usually & 16 & 22.6(17.4- 27) & \multirow[t]{2}{*}{0.672} \\
\hline & & Never & 33 & $21.8(16.6-32.5)$ & \\
\hline & Photoprotection over 18 years old & Usually & 35 & 19.7(16.8- 27.4) & 0.824 \\
\hline & & Never & 36 & $21.7(16-31.8)$ & \\
\hline Melanoma characteristic* & Number of Melanoma & SPM & 62 & $20.5(16.4-27.4)$ & 0.992 \\
\hline & & MPM & 19 & 21.6(16.8- 31.1) & \\
\hline & Breslow thickness & $<=0.75$ & 31 & 19(13.8- 29.3) & 0.544 \\
\hline & & $0.75-1$ & 15 & $22.2(17.8-26)$ & \\
\hline & & $>=1$ & 22 & 23.1(16.6- 31.1) & \\
\hline
\end{tabular}

The medians $\left(25^{\text {th }}-75^{\text {th }}\right.$ percentiles) of 25 -hydroxyvitamin D3 levels were reported. P-values were calculated by U Mann Whitney or Wilcoxon test. *Not all the patients have complete data.

where the parathyroid hormone has its maximum inhibition [34]. Using this definition, $32 \%$ of patients had adequate levels $(>25 \mathrm{ng} / \mathrm{ml})$ and $68 \%$ had insufficient levels $(\leq 25 \mathrm{ng} / \mathrm{ml}$ ) of 25-hydroxyvitamin D3 (Table 2).

The relationship between 25-hydroxyvitamin D3 levels, as a dichotomous variable, and clinical characteristics was showed in Table 2. The group with insufficient 25hydroxyvitamin D3 level $(\leq 25 \mathrm{ng} / \mathrm{ml})$ differed from those with appropriate 25-hydroxyvitamin D3 ( $>25 \mathrm{ng} / \mathrm{ml})$ in season of blood sampling $(P=0.012)$, solar exposure between $10-18$ years $(P=0.049)$ and skin type $(P=0.05)$ (Table 2). Since patient recollection of solar exposure 


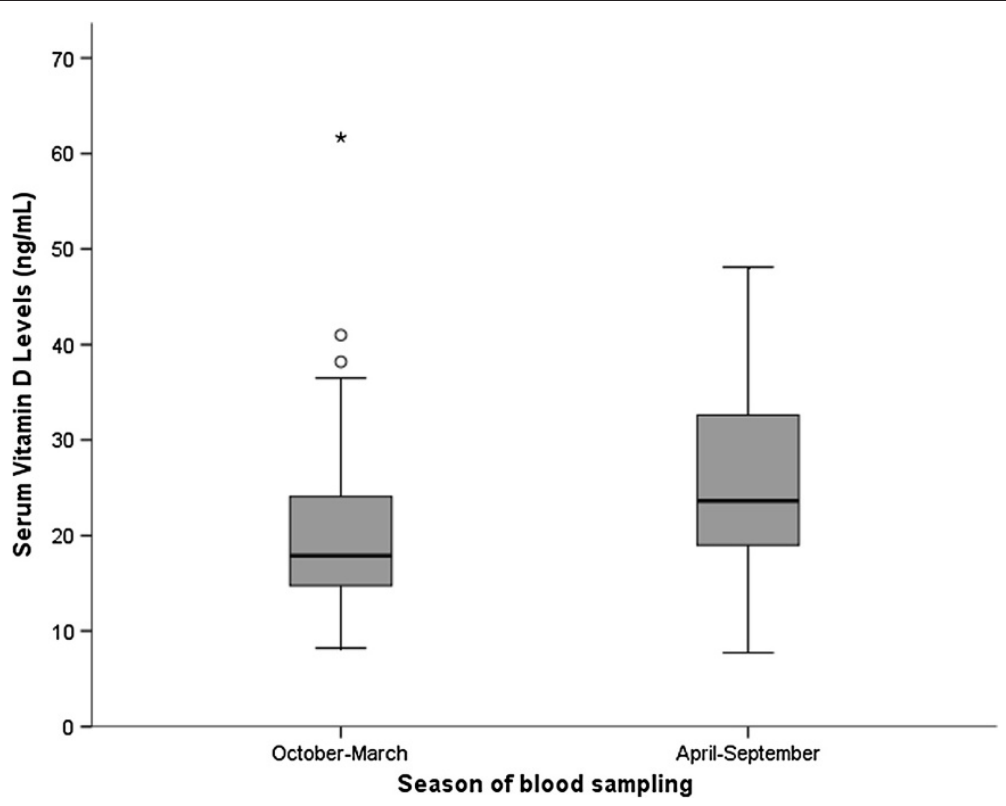

Figure 1 Variation in serum 25-hydroxyvitamin D3 levels by season of blood sampling. The circles represent high 25-hydroxyvitamin D3 values $(38.2 \mathrm{ng} / \mathrm{ml}$ and $41 \mathrm{ng} / \mathrm{ml}$ ) and the asterisk the highest 25-hydroxyvitamin D3 value $61.7 \mathrm{ng} / \mathrm{ml}$.

may be subject to response and recall bias, solar exposure variable was not included in multivariate analysis.

After multivariate logistic regression analysis, season of sampling remained the only predictors of 25hydroxyvitamin D3 levels, independent of gender or skin type (Table 3).

\section{VDR polymorphisms}

Clinical characteristics, habits of solar exposure and melanoma data of patients are resumed in Table 4. The median age at melanoma diagnosis was 45 years (33-59.8), considering all patients. Significant differences between cases with $<50$ nevi and cases with $>100$ nevi were found such as age at melanoma diagnosis $(P<0.001)$ and number of melanomas $(P<0.001)$ (Table 4$)$. Patients with multiple nevi were younger (median 39 years) and have more multiple melanomas (55\%) than patients with few nevi (median 49 years; $20 \%$ with melanoma multiple).

A total of 10 out of 11 SNPs were successfully genotyped in 263 melanoma patients. SNP rs739837 (BglI) failed genotype analysis. All the 10 SNPs followed HWE in the reference group (cases with <50) (Table 4). Genotyping quality was confirmed with $100 \%$ concordance between duplicates.

Differences in genotype distributions between cases with $<50$ nevi and cases with $>100$ nevi were significant for 3 VDR SNPs: rs2189480 (OR $=1.80$, 95\%IC (1.17$\left.2.76) ; \quad P_{\text {additive }}=0.006\right), \quad \mathrm{rs} 2239179 \quad(\mathrm{OR}=0.67,95 \% \mathrm{IC}$ (0.46-0.99); $\left.P_{\text {additive }}=0.044\right)$ and $\operatorname{rs7975128}(\mathrm{OR}=0.51$, 95\%IC (0.35-0.76); $\left.P_{\text {additive }}=0.0005\right)$, adjusted for age and gender. An additional SNP rs3782905, significant under recessive model $(\mathrm{OR}=0.21,95 \% \mathrm{IC}(0.07-0.66)$; $P_{\text {recessive }}=0.0025$ ), was not further considered as this effect is likely due to small number of individuals homozygous for this rare allele with high nevus number. Use of the Bonferroni test supported a significant association with nevus number only for rs7975128. Although SNP rs2239179 was no longer significant $\left(P_{\text {additive }}=0.06\right)$, adjustment for number of melanomas, as confounding variable, did not result in substantial OR variation for all three SNPs (Table 5).

Sub-group analysis revealed that rs7975128 was associated with decreased risk of multiple primary melanoma $\left(\mathrm{OR}=0.64 \quad 95 \% \mathrm{CI} \quad(0.43-0.94) ; P_{\text {additive }}=0.021\right)$ and with light eye color $(\mathrm{OR}=1.4895 \% \mathrm{CI}(1.00-2.19)$; $P_{\text {additive }}=0.049$ ).

\section{Discussion}

Our work is the first study to describe 25-hydroxyvitamin D3 insufficiency in melanoma patients from Spain. Furthermore, the association between $V D R$ SNPs and nevus number, an established risk factor for melanoma, was also evaluated.

The optimal level of 25-hydroxyvitamin D3 remains contentious ${ }^{4}$. Several meta-analyses support the evidence that low 25-hydroxyvitamin D3 serum level, which is highly prevalent worldwide, is a risk factor for many chronic diseases including cancer [35]. The minimum desirable serum level of 25-hydroxyvitamin D3 has been suggested to be between $20 \mathrm{ng} / \mathrm{ml}$ and $30 \mathrm{ng} / \mathrm{ml}$ [36]. In 
Table 2 Association between clinical characteristics and suboptimal 25-hydroxyvitamin D3 levels at time of diagnosis in melanoma patients

\begin{tabular}{|c|c|c|c|c|c|c|}
\hline & Variables* & & $\begin{array}{l}\text { VitD level } \\
\text { sufficient } \\
>25 \mathrm{ng} / \mathrm{mL} \\
\mathrm{n}=26(32 \%)\end{array}$ & $\begin{array}{l}\text { VitD level } \\
\text { insufficient } \\
\leq 25 \mathrm{ng} / \mathrm{mL} \\
\mathrm{n}=55(68 \%)\end{array}$ & OR $(95 \% \mathrm{IC})$ & $P$ \\
\hline \multirow[t]{18}{*}{ Clinical characteristic } & Age at diagnosis of melanoma** & & $54(36-65)$ & $55(37-68)$ & $0.99(0.96-1.01)$ & 0.553 \\
\hline & Gender & Female & $15(57.7 \%)$ & $23(41.8 \%)$ & 1 & \\
\hline & & Male & $11(42.3 \%)$ & $32(58.2 \%)$ & $1.9(0.74-4.88)$ & 0.184 \\
\hline & BMI basal (kg/m2) & Normal weight & $9(47.4 \%)$ & $15(34.1 \%)$ & 1 & \\
\hline & & Overweight & $6(31.6 \%)$ & $18(40.9 \%)$ & $0.56(0.16-1.92)$ & 0.353 \\
\hline & & Obese & $4(21.1 \%)$ & $11(25 \%)$ & $0.61(0.16-2.49)$ & 0.487 \\
\hline & Season blood sampling & Spring- Summer & $18(69.2 \%)$ & $20(38.5 \%)$ & 1 & \\
\hline & & Autumn- Winter & $8(30.8 \%)$ & $32(61.5 \%)$ & $3.6(1.32-9.81)$ & 0.012 \\
\hline & Fitzpatrick skin type & Dark & $16(61.5 \%)$ & $21(38.2 \%)$ & 1 & \\
\hline & & Fair & $10(38.5 \%)$ & $34(61.8 \%)$ & $2.59(0.99-6.76)$ & 0.052 \\
\hline & Hair color & Dark & $8(30.8 \%)$ & $32(61.5 \%)$ & 1 & \\
\hline & & Light & $8(32 \%)$ & $15(29.4 \%)$ & $0.89(0.32-2.49)$ & 0.818 \\
\hline & Eye color & Dark & $11(44 \%)$ & $27(54 \%)$ & 1 & \\
\hline & & Light & $14(56 \%)$ & $23(46 \%)$ & $0.67(0.26-1.76)$ & 0.415 \\
\hline & Actinic damage & No & $21(80.8 \%)$ & $41(78.8 \%)$ & 1 & \\
\hline & & Yes & $5(19.2 \%)$ & $11(21.2 \%)$ & $0.89(0.27-2.89)$ & 0.843 \\
\hline & Nevus Number & $<50$ & $12(54.5 \%)$ & $22(53.7 \%)$ & 1 & \\
\hline & & $\geq 50$ & $10(45.5 \%)$ & $19(46.3 \%)$ & $0.97(0.34-2.73)$ & 0.946 \\
\hline \multirow{12}{*}{$\begin{array}{l}\text { Habits of solar exposure } \\
\text { and photoprotection }\end{array}$} & Solar exposure before 10 years old & Severe/Moderate & $21(80.8 \%)$ & $38(73.1 \%)$ & 1 & \\
\hline & & None/Mild & $5(19.2 \%)$ & $14(26.9 \%)$ & $1.55(0.49-4.9)$ & 0.458 \\
\hline & Solar exposure $10-18$ years old & Severe/Moderate & $23(88.5 \%)$ & $34(66.7 \%)$ & 1 & \\
\hline & & None/Mild & $3(11.5 \%)$ & 17(33.3\%) & $3.83(1.01-14.5)$ & 0.049 \\
\hline & Solar exposure $>18$ years old & Severe/Moderate & $11(91.7 \%)$ & $18(64.3 \%)$ & 1 & \\
\hline & & None/Mild & $1(8.3 \%)$ & $10(35.7 \%)$ & $6.11(0.68-54.5)$ & 0.105 \\
\hline & Photoprotection before 10 years old & Never & $17(68 \%)$ & $30(63.8 \%)$ & 1 & \\
\hline & & Usually & $8(32 \%)$ & $17(36.2 \%)$ & $1.20(0.43-3.37) .33)$ & 0.724 \\
\hline & Photoprotection $10-18$ years old & Never & $14(73.3 \%)$ & $19(63.3 \%)$ & 1 & \\
\hline & & Usually & $5(26,3 \%)$ & $11(36.7 \%)$ & $1.62(0.46-5.73)$ & 0.453 \\
\hline & Photoprotection over 18 years old & Never & $15(60 \%)$ & $21(45.7 \%)$ & 1 & \\
\hline & & Usually & $10(40 \%)$ & $25(54.3 \%)$ & $1.79(0.66-4.80)$ & 0.250 \\
\hline \multirow[t]{6}{*}{ Melanoma characteristic } & Number of Melanoma & SPM & $24(92.3 \%)$ & $49(89.1 \%)$ & 1 & \\
\hline & & MPM & $2(7.7 \%)$ & $6(10.9 \%)$ & $0.68(0.13-3.63)$ & 0.652 \\
\hline & Breslow thickness $^{+}$ & $<=0.75$ & $22(46.8 \%)$ & 9 (42.9\%) & 1 & \\
\hline & & $0.75-1$ & $11(23.4 \%)$ & $4(19.0 \%)$ & $0.89(0.22-3.54)$ & 0.867 \\
\hline & & $>=1$ & $14(29.8 \%)$ & $8(38.1)$ & $1.4(0.43-4.48)$ & 0.574 \\
\hline & Breslow thickness ${ }^{+* *}$ & & $0.8(0.52-1.3)$ & $0.8(0.52-1.2)$ & $1.1(0.78-1.54)$ & 0.583 \\
\hline
\end{tabular}

VitD $=25$-hydroxyvitamin D3 ${ }^{*}$ Not all the patients have complete data ${ }^{+}$Breslow thickness was analized as categorical and continuos variable ${ }^{*}$ The medians $\left(25^{\text {th }}-75^{\text {th }}\right.$ percentiles) of 25 -hydroxyvitamin D3 levels were reported for age at diagnosis of melanoma and breslow thickness. 
Table 3 Multivariate models for prediction of presence of low levels of 25-Hydroxyvitamin D3

\begin{tabular}{llll}
\hline $\mathbf{N}$ Model & Variables & OR (95\%Cl) & $\boldsymbol{P}$ \\
\hline 1 & $\begin{array}{l}\text { Season blood sampling } \\
\text { (October- March) }\end{array}$ & $3.25(1.17-9.03)$ & 0.024 \\
& $\begin{array}{l}\text { Skin phototype (Fair) } \\
2\end{array}$ & $2.21(0.81-6.04)$ & 0.123 \\
& $\begin{array}{l}\text { Season blood sampling } \\
\text { (October- March) }\end{array}$ & $3.3(1.17-9.27)$ & 0.024 \\
& Skin phototype (Fair) & $2.33(0.84-6.46)$ & 0.105 \\
& Gender (Male) & $1.88(0.68-5.21)$ & 0.227 \\
\hline
\end{tabular}

Model 1. Estimation of presence of low levels of 25-Hydroxyvitamin D3 by season blood sampling adjusted by skin phototype.

Model 2. Estimation of presence of low levels of 25-Hydroxyvitamin D3 by season blood sampling adjusted by skin phototype and gender.

Multivariate logistic regression models for estimation of presence of low levels of 25-Hydroxyvitamin D3 suggest that season blood sampling in autumnwinter (October-March) months is the only predictor of low 25 -Hydroxyvitamin D3, independently from skin phototype and gender.

2011 The IOM committee reported guidelines stating that a level of 25-hydroxyvitamin D3 $>20 \mathrm{ng} / \mathrm{ml}$ is needed for good bone and general health for practically all individuals [37]. However, the IOM report did not consider clinical and demographic variables (ie: race/ethnicity, adiposity, body composition, sun exposure, etc.) by which 25-hydroxyvitamin D3 levels are notoriously affected. Recently, a meta-analysis involving 59231 healthy subjects from eleven prospective cohort studies suggested that the optimal 25-hydroxyvitamin D3 concentrations of between $30 \mathrm{ng} / \mathrm{ml}$ and $40 \mathrm{ng} / \mathrm{ml}(75$ $\mathrm{nmol} / \mathrm{L}$ and $100 \mathrm{nmol} / \mathrm{L}$ ) are needed to reduce mortality [38]. The majority of authors site the cut off as $<30 \mathrm{ng} / \mathrm{ml}$ as this level is reported to correlate with leveling off of the parathyroid hormone (PTH) level. The level chosen as cut off varied in studies in European populations [39]. In our study a conservative level of $\leq 25 \mathrm{ng} / \mathrm{ml}$ as 25-hydroxyvitamin D3 insufficiency was chosen as reported in a previous study in melanoma patients [5]. Using this definition, most of our patients (68\%) at the time of melanoma diagnosis had suboptimal levels of 25-hydroxyvitamin D3. Newton-Bishop et al. [5] determined the levels of 25hydroxyvitamin D3 in 1132 patients with melanoma from the North of England (Leeds), where insufficient levels of 25 -hydroxyvitamin D3 was found in $64 \%$ of patients, a proportion comparable to our study. In the same study, 25-hydroxyvitamin D3 levels were associated with Breslow thickness. In contrast to the UK study, we did not found any association between 25-hydroxyvitamin D3 and Breslow thickness as the majority of our melanoma patients has Breslow thickness $<2 \mathrm{~mm}$.

The prevalence of insufficiency in Spain, a Mediterranean country with many hours of sunshine and where tanning is considered indicative of a healthy and attractive status, was therefore unexpected. 25-hydroxyvitamin D3 levels in general Spanish population have been reported to be insufficiency by studies tended to be small

Table 4 Clinical characteristics of patients with low $(<50)$ and high $(>100)$ nevus number

\begin{tabular}{|c|c|c|c|c|c|}
\hline & Variables* & & $\begin{array}{l}\text { Cases }<50(\%) \\
n=150\end{array}$ & $\begin{array}{l}\text { Cases }>100(\%) \\
n=113\end{array}$ & $P$ \\
\hline \multirow[t]{11}{*}{ Clinical characteristic } & Age at melanoma diagnosis* & & $49(34-64)$ & $39(32-50)$ & $<0.001$ \\
\hline & Gender & Male & $68(45.3)$ & $51(45.1)$ & 1.000 \\
\hline & & Female & $82(54.7)$ & $62(54.9)$ & \\
\hline & Fitzpatrick skin type & Dark & $80(58.4)$ & $43(45.7)$ & 0.061 \\
\hline & & Fair & $57(41.6)$ & $51(54.3)$ & \\
\hline & Hair colour & Dark & 107(77.5) & $71(75.5)$ & 0.723 \\
\hline & & Light & $31(22.5)$ & $23(24.5)$ & \\
\hline & Eye colour & Dark & $90(66.2)$ & $60(64.5)$ & 0.795 \\
\hline & & Light & 46(33.8) & $33(35.5)$ & \\
\hline & Actinic Damage & No & $99(85.3)$ & $64(85.3)$ & 0.988 \\
\hline & & Yes & $17(14.7)$ & $11(14.7)$ & \\
\hline \multirow[t]{6}{*}{ Habits of solar exposure } & Solar exposure before 10 years old & None/Mild & $53(41.4)$ & $28(29.5)$ & 0.067 \\
\hline & & Severe/Moderate & $75(58.6)$ & $67(70.5)$ & \\
\hline & Solar exposure 10-18 years old & None/Mild & $30(23.8)$ & $26(27.7)$ & 0.517 \\
\hline & & Severe/Moderate & $96(76.2)$ & $68(72.3)$ & \\
\hline & Solar exposure over 18 years old & None/Mild & 26(20.6) & $24(25.8)$ & 0.367 \\
\hline & & Severe/Moderate & 100(79.4) & $69(74.2)$ & \\
\hline \multirow[t]{2}{*}{ Melanoma characteristic } & Number of melanoma & SPM & $120(80)$ & $50(44.2)$ & $<0.001$ \\
\hline & & MPM & $30(20)$ & 63(55.8) & \\
\hline
\end{tabular}

${ }^{*}$ Not all the patients have complete phenotype data. ${ }^{* *}$ The median $\left(25^{\text {th }}-75^{\text {th }}\right.$ percentile) of age at diagnosis of melanoma was reported. 
Table 5 Association between VDR polymorphisms and nevus number

\begin{tabular}{|c|c|c|c|c|c|c|c|c|c|c|c|c|}
\hline & SNP & Position* & Change & MAF\% & HWE $P \wedge$ & Genotype & Cases $<50(\%)$ & Cases $>100(\%)$ & OR $(95 \% C l)^{a}$ & $P_{\text {additive }}^{a}$ & OR $(95 \% C l)^{b}$ & $P_{\text {additive }}^{b}$ \\
\hline \multirow[t]{4}{*}{1} & rs7136534 & 48294626 & $\mathrm{C} / \mathrm{T}$ & 0.18 & 0.400 & $\mathrm{C} / \mathrm{C}$ & $101(68.7)$ & $70(65.4)$ & 1.00 & & & \\
\hline & & & & & & $\mathrm{T} / \mathrm{C}$ & $40(27.2)$ & $33(30.8)$ & $1.15(0.65-2.02)$ & & & \\
\hline & & & & & & $\mathrm{T} / \mathrm{T}$ & $6(4.1)$ & $4(3.7)$ & $0.78(0.21-2.94)$ & & & \\
\hline & & & & & & additive & & & $1.03(0.65-1.62)$ & 0.903 & $1.18(0.73-1.92)$ & 0.504 \\
\hline \multirow[t]{4}{*}{2} & rs11574027 & 48287373 & $\mathrm{G} / \mathrm{T}$ & 0.10 & 1.000 & $\mathrm{G} / \mathrm{G}$ & 119 (82.1\%) & 86 (78.9\%) & 1.00 & & & \\
\hline & & & & & & $\mathrm{T} / \mathrm{G}$ & $25(17.2 \%)$ & $23(21.1 \%)$ & $1.35(0.71-2.57)$ & & & \\
\hline & & & & & & $\mathrm{T} / \mathrm{T}$ & $1(0.7 \%)$ & $0(0 \%)$ & NA & & & \\
\hline & & & & & & additive & & & $1.19(0.64-2.21)$ & 0.580 & $1.30(0.67-2.52)$ & 0.431 \\
\hline \multirow[t]{4}{*}{3} & rs11168287 & 48285414 & $\mathrm{G} / \mathrm{A}$ & 0.44 & 0.869 & $\mathrm{G} / \mathrm{G}$ & $43(29.3)$ & $36(33.0)$ & 1.00 & & & \\
\hline & & & & & & $A / G$ & $72(49.0)$ & $57(52.3)$ & $0.99(0.55-1.76)$ & & & \\
\hline & & & & & & $\mathrm{A} / \mathrm{A}$ & $32(21.8)$ & $16(14.7)$ & $0.58(0.27-1.24)$ & & & \\
\hline & & & & & & additive & & & $0.79(0.55-1.14)$ & 0.212 & $0.83(0.56-1.23)$ & 0.352 \\
\hline \multirow[t]{4}{*}{4} & rs2238136 & 48277713 & $\mathrm{G} / \mathrm{A}$ & 0.24 & 0.349 & $\mathrm{G} / \mathrm{G}$ & $86(60.1)$ & $52(52.5)$ & 1.00 & & & \\
\hline & & & & & & $\mathrm{A} / \mathrm{G}$ & $47(32.9)$ & $44(44.4)$ & $1.61(0.93-2.79)$ & & & \\
\hline & & & & & & $\mathrm{A} / \mathrm{A}$ & $10(7.0)$ & $3(3.0)$ & $0.47(0.12-1.82)$ & & & \\
\hline & & & & & & additive & & & $1.11(0.72-1.72)$ & 0.636 & $1.05(0.66-1.67)$ & 0.845 \\
\hline \multirow[t]{4}{*}{5} & rs3782905 & 48266167 & $C / G$ & 0.36 & 0.483 & $\mathrm{C} / \mathrm{C}$ & $52(35.9)$ & $42(38.5)$ & 1.00 & & & \\
\hline & & & & & & $C / G$ & $74(51.0)$ & $63(57.8)$ & $1.07(0.62-1.83)$ & & & \\
\hline & & & & & & $\mathrm{G} / \mathrm{G}$ & $19(13.1)$ & $4(3.7)$ & $0.22(0.07-0.71)$ & & & \\
\hline & & & & & & additive & & & $0.70(0.46-1.06)$ & 0.134 & $0.69(0.44-1.08)$ & 0.099 \\
\hline \multirow[t]{5}{*}{6} & rs2189480 & 48263828 & $\mathrm{G} / \mathrm{T}$ & 0.35 & 0.238 & $\mathrm{G} / \mathrm{G} * *$ & & & $0.21(0.07-0.66)$ & & & \\
\hline & & & & & & $\mathrm{G} / \mathrm{G}$ & $65(45.5)$ & $30(28.6)$ & 1.00 & & & \\
\hline & & & & & & $T / G$ & $68(47.6)$ & $63(60.0)$ & $1.92(1.09-3.39)$ & & & \\
\hline & & & & & & $\mathrm{T} / \mathrm{T}$ & $10(7.0)$ & $12(11.4)$ & $2.97(1.12-7.87)$ & & & \\
\hline & & & & & & additive & & & $1.80(1.17-2.76)$ & 0.006 & $1.66(1.05-2.60)$ & 0.027 \\
\hline \multirow[t]{4}{*}{7} & rs2239179 & 48257766 & $A / G$ & 0.44 & 0.192 & A/A & $35(23.5)$ & $36(33.3)$ & 1.00 & & & \\
\hline & & & & & & $A / G$ & $83(55.7)$ & $58(53.7)$ & $0.70(0.39-1.26)$ & & & \\
\hline & & & & & & $\mathrm{G} / \mathrm{G}$ & $31(20.8)$ & $14(13.0)$ & $0.44(0.20-0.99)$ & & & \\
\hline & & & & & & additive & & & $0.67(0.46-0.99)$ & 0.044 & $0.67(0.44-1.02)$ & 0.060 \\
\hline \multirow[t]{4}{*}{8} & rs11574077 & 48252927 & $\mathrm{~T} / \mathrm{C}$ & 0.05 & 0.463 & $\mathrm{~T} / \mathrm{T}$ & 129(87.8) & $104(93.7)$ & 1.00 & & & \\
\hline & & & & & & $\mathrm{T} / \mathrm{C}$ & 17 (11.6) & $7(6.3)$ & $0.54(0.21-1.38)$ & & & \\
\hline & & & & & & $C / C$ & $1(0.7)$ & $0(0.0)$ & NA & & & \\
\hline & & & & & & additive & & & $0.52(0.21-1.27)$ & 0.135 & $0.45(0.17-1.18)$ & 0.088 \\
\hline
\end{tabular}


Table 5 Association between VDR polymorphisms and nevus number (Continued)

\begin{tabular}{|c|c|c|c|c|c|c|c|c|c|c|c|c|}
\hline \multirow[t]{4}{*}{$\overline{9}$} & rs11168267 & 48251542 & $\mathrm{C} / \mathrm{T}$ & 0.07 & 1.000 & $\mathrm{C} / \mathrm{C}$ & $128(85.9)$ & $98(88.3)$ & 1.00 & & & \\
\hline & & & & & & $\mathrm{T} / \mathrm{C}$ & $21(14.1)$ & $12(10.8)$ & $0.68(0.32-1.48)$ & & & \\
\hline & & & & & & $\mathrm{T} / \mathrm{T}$ & $0(0.0)$ & $1(0.9)$ & NA & & & \\
\hline & & & & & & additive & & & $0.84(0.41-1.72)$ & 0.626 & $0.84(0.38-1.84)$ & 0.656 \\
\hline \multirow[t]{4}{*}{10} & rs7975128 & 48245828 & $\mathrm{G} / \mathrm{A}$ & 0.33 & 0.385 & $\mathrm{G} / \mathrm{G}$ & $56(38.6)$ & $63(58.9)$ & 1.00 & & & \\
\hline & & & & & & $\mathrm{A} / \mathrm{G}$ & $64(44.1)$ & $35(32.7)$ & $0.47(0.27-0.82)$ & & & \\
\hline & & & & & & A/A & 25 (17.2) & $9(8.4)$ & $0.29(0.12-0.69)$ & & & \\
\hline & & & & & & additive & & & $0.51(0.35-0.76)$ & 0.0005 & $0.58(0.38-0.87)$ & 0.007 \\
\hline
\end{tabular}

MAF minor allele frequency.

*SNP position from NCBl; $\wedge$ HWE Hardy -Weinberg Equilibrium for cases with low number of nevi (cases $<50$ ) as reference group; $a=$ adjusted for age and gender; $b=$ adjusted for age. gender and number of melanoma.

** recessive model for SNP rs3782905. 
and in different sub-groups of the population [40-42]. The largest study analyzed 25-hydroxyvitamin D3 level in 1262 individuals from Spain and reported 25-hydroxyvitamin D3 insufficiency in one-third (33\%) of the population [43].

Consistent with previous finding [5], there was seasonal variation in serum levels of 25-hydroxyvitamin D3 where 25-hydroxyvitamin D3 levels were lower in autumn-winter months.

The role of solar exposure in melanoma is complex as, on the one hand, it is a strong risk factor for melanoma, and, on the other, lack of solar exposure leads to 25hydroxyvitamin D3 deficiency. It has been recently reported that regular weekend solar exposure is protective against melanoma [44] and is associated with increased 25-hydroxyvitamin D3 levels [45]. We have observed a correlation between less solar exposure during adolescence and insufficient 25-hydroxyvitamin D3 levels. However this result has to be interpreted with caution as self- reported past solar exposure is subject to recall bias.

In our study, 25-hydroxyvitamin D3 levels at the time of diagnosis were lower in fair-skinned patients than darker ones. Although this relationship was no longer statistically significant when corrected for season, this may reflect low statistical power. However, three other studies have in fact also reported that within whiteskinned populations, fair skinned people have lower levels of 25-hydroxyvitamin D3 [45-47].

It was postulated that lower levels of 25hydroxyvitamin D3 in individuals with fair skin reflect their habits of sun protection and in fact, this group of patients did report fewer hours of daily sun exposure and greater use of sunscreen than patients with darker skin type (data not shown). Our results support the hypothesis that increased photoprotection practices may contribute to increase 25hydroxyvitamin D3 deficiency although the results are still contradictory [48-50].

The effects of 25-hydroxyvitamin D3 are mediated by $V D R$ and SNPs in this gene are expected to influence the anti-proliferative activity of 25-hydroxyvitamin D3 in melanocytes. The potential role of functional $V D R$ variants such as FokI and BsmI in melanoma risk has been assessed by meta-analysis studies [22,23]. In our study, significant associations have been detected between nevus number, the most potent phenotypic risk factor of melanoma and 3 out of 11 VDR SNPs. The SNP rs2189480 was associated with risk of having a high number of nevi whereas SNPs rs7975128 and rs2239179 with decreased risk of having a high number of nevi. All 3 SNPs are localized in the VDR coding region between SNPs FokI and BsmI and have been previously described in other pathologies [50-52]. After Bonferroni correction, only SNP rs7975128 remained significant.
When we analyzed the effect of $V D R$ variant and melanoma susceptibility, we found that SNP rs7975218 was also associated with decreased risk of multiple primary melanomas. Recently, in a large case-only study, $8 \mathrm{VDR}$ SNPs, 6 not previously studied, were associated with melanoma susceptibility [24]. As Orlow et al. [24] report, the present work confirmed the efficiency of the tagSNP method and showed that information about the genetic variability of $V D R$ is still incomplete.

According to HapMap, rs7975218 is in complete LD $(\mathrm{r} 2=1)$ with $V D R$ functional variants $B s m \mathrm{I}$ and TaqI (rs731236) which formed a block in tight LD, including also ApaI (rs7975232), located at the 3'UTR region of $V D R$. Consistent with previous findings in melanoma where, both TaqI and BsmI have been shown to be protective against melanoma risk [21-23], SNP rs7975128 showed a protective tendency for high nevus number and number of melanoma.

By functional study, Carling et al. [53] have demonstrated that baT (haplotype of BsmI/ApaI/TaqI) is associated with low VDR mRNA expression. The 3'UTR variants are thought to affect VDR mRNA stability [18] but the functionality of these variants is still unclear [22].

We also reported an association between SNP rs7975128 and light eye color, which, with pigmentary features such as light hair and fair skin, is considered a melanoma risk factor related to sun exposure. Although the significance of this association is not clear, the presence of this SNP among patients with light eye color could suggest the involvement of the VDR gene in melanoma predisposition among a subgroup of patients at risk of low 25-hydroxyvitamin D3. Relationship between $V D R$ genetic variants and phenotype features among melanoma patients has been previously described [16].

The only report in a Spanish population found significant associations between VDR SNPs and clinical characteristics such as fair skin, absence of childhood sunburns and tumor in head-neck and trunk but not with melanoma risk, suggesting that $V D R$ may modulate melanoma susceptibility [29].

Studies including only melanoma patients have been shown to be valid in identifying rare genetic variants associated with melanoma predisposition as rare variants have a higher prevalence among cases [24,54].

The limitations of our study should be considered. The small sample size of the two groups of patients may affect our results; however the proportion of patients with insufficient 25-hydroxyvitamin D3 is comparable to a previous study in a larger melanoma population [5]. Information regarding dietary and 25hydroxyvitamin D3 supplement sources, conditions that may affect 25-hydroxyvitamin D3 levels, were not taken into account in the analysis as not available. 


\section{Conclusions}

Information on both serum 25-hydroxyvitamin D3 levels and $V D R$ variants are required to understand the role of 25-hydroxyvitamin D3 in melanoma risk. High prevalence of sub-optimal levels of 25-hydroxyvitamin D3 was found among melanoma patients at diagnosis. The relationship between VDR SNP rs7975128 and, respectively, low nevus number and less multiple primary melanoma, suggests the involvement of VDR, and in turn of 25-hydroxyvitamin D3, in melanoma susceptibility.

Our results provide further evidence that 25-hydroxyvitamin D3 could be involved in melanoma etiology in a population from Barcelona, a Mediterranean area characterized by a sunny climate. However this finding needs to be validated in a larger sample.

\section{Competing interests}

The authors declare that they have no competing interests.

\section{Authors' contributions}

ZO was involved in collecting the samples, genotyping analysis, acquisition of the data, association analysis, interpretation of the data and wrote the manuscript. LV was involved in acquisition of the 25-hydroxyvitamin D3 data, interpretation of the data and wrote the manuscript; CB, JAPB were involved in design of the study and collecting the samples; JMA performed 25hydroxyvitamin D3 measurements; JR, NB, EG, MAP performed statistical analysis; CC, IK, JM were involved in patients recruitment; SP conceived the study, participated in its design and coordination, in interpretation of the data and drafting the manuscript. All authors contributed to critical revision of the manuscript and read and approved the final manuscript.

\section{Acknowledgements}

The Barcelona team's research has been supported by Fondo de Investigaciones Sanitarias (grants 05/0302, 06/0265 and 09/1393) and by the European Commission under the 6th Framework Programme, Contract nr: LSHC-CT-2006-018702 (GenoMEL) and by the National Cancer Institute (NCI) of the US National Institute of Health (NIH) (CA83115). Zighereda Ogbah was supported by financial support provided by Agència de Gestió d'Ajuts Universitaris i de Recerca (AGAUR).We also thank the principal investigators of the GenoMEL founding grants David Elder, Julia Newton Bishop and Nelleke Gruis for their support and the leader of the exchange Programme Giovanna Bianchi-Scarrá and also Linda Battistuzzi. Thanks to research nurses from the Melanoma Unit of Hospital Clínic of Barcelona, Daniel Gabriel and Pablo Iglesias for collecting phenotype data of patients; to Michael Churchman from LIMM (Leeds) for genotyping support; and to Helena Kruyer for helping with the English editing and correction of the manuscript. This work was developed in the Melanoma Units of Hospital Clinic I Provincial de Barcelona, IDIBAPS; the Bioinformatics and Biostatistics Unit, and Translational Research Laboratory, Catalan Institute of Oncology, Bellvitge Biomedical Research Institute (IDIBELL), L'Hospitalet, Barcelona, Spain; and in Epidemiology and Biostatistics, LIMM, University of Leeds.

\section{Author details}

'Melanoma Unit, Department of Dermatology Hospital Clínic de Barcelona, IDIBAPS, Barcelona University, Barcelona, Spain. ${ }^{2}$ Melanoma Unit, Biochemistry and Molecular Genetics Service, Hospital Clínic de Barcelona, IDIBAPS, Barcelona University, Barcelona, Spain. ${ }^{3}$ Centre of Biomedical Research on Rare Diseases (CIBERER), ISCIII, Barcelona, Spain. ${ }^{4}$ Statistics and Methodological Support Unit, Unitat d'Avaluació, Suport i Prevenció (UASP), Hospital Clínic, IDIBAPS, Barcelona, Spain. ${ }^{5}$ Bioinformatics and Biostatistics Unit, and Translational Research Laboratory, Catalan Institute of Oncology, Bellvitge Biomedical Research Institute (IDIBELL), L'Hospitalet, Barcelona, Spain.

Received: 23 July 2012 Accepted: 12 February 2013

Published: 16 February 2013
References

1. Garland CF, Garland FC, Gorham ED, Lipkin M, Newmark H, Mohr SB, Holick MF: The role of vitamin D in cancer prevention. Am J Public Health 2006, 96:252-261.

2. Borradale D, Kimlin M: Vitamin D in health and disease: an insight into traditional functions and new roles for the 'sunshine vitamin'. Nutr Res Rev 2009, 22:118-136.

3. Holick MF: Vitamin D deficiency in 2010: health benefits of vitamin D and sunlight: a D-bate. Nat Rev Endocrinol 2011, 7:73-75.

4. Field S, Newton-Bishop JA: Melanoma and vitamin D. Mol Oncol 2011 5:197-214

5. Newton-Bishop JA, Beswick S, Randerson-Moor J, Chang YM, Affleck P, Elliott F, Chan M, Leake S, Karpavicius B, Haynes S, Kukalizch K, Whitaker L, Jackson S, Gerry E, Nolan C, Bertram C, Marsden J, Elder DE, Barrett JH, Bishop DT: Serum 25-hydroxyvitamin D3 levels are associated with breslow thickness at presentation and survival from melanoma. J Clin Oncol 2009, 27:5439-5444.

6. Nurnberg B, Graber S, Gartner B, Geisel J, Pfohler C, Schadendorf D, Tilgen W, Reichrath J: Reduced serum 25-hydroxyvitamin D levels in stage IV melanoma patients. Anticancer Res 2009, 29:3669-3674.

7. Gandini S, Sera F, Cattaruzza MS, Pasquini P, Picconi O, Boyle P, Melchi CF: Meta-analysis of risk factors for cutaneous melanoma: II Sun exposure. Eur J Cancer 2005, 41:45-60.

8. Holick MF: Sunlight and vitamin D for bone health and prevention of autoimmune diseases, cancers, and cardiovascular disease. Am J Clin Nutr 2004, 80(Suppl 6):1678S-1688S.

9. Holick MF: Vitamin D, deficiency. N Engl J Med 2007, 357:266-281.

10. Dusso AS, Brown AJ, Slatopolsky E: Vitamin D. Am J Physiol Renal Physiol 2005, 289:F8-F28.

11. Seifert M, Rech M, Meineke V, Tilgen W, Reichrath J: Differential biological effects of 1,25-dihydroxyVitamin D3 on melanoma cell lines in vitro. $J$ Steroid Biochem Mol Biol 2004, 89-90:375-379.

12. Ranson M, Posen S, Mason RS: Human melanocytes as a target tissue for hormones: in vitro studies with 1 alpha-25, dihydroxyvitamin D3, alphaMelanocyte stimulating hormone, and beta-Estradiol. $J$ Invest Dermatol 1988, 91:593-598.

13. Whitfield GK, Hsieh JC, Jurutka PW, Selznick SH, Haussler CA, MacDonald PN, Haussler MR: Genomic actions of 1,25-dihydroxyvitamin D3. Journal Nutr 1995, 125(Suppl 6):1690S-1694S.

14. Nejentsev S, Godfrey L, Snook H, Rance H, Nutland S, Walker NM, Lam AC, Guja C, lonescu-Tirgoviste C, Undlien DE, Rønningen KS, Tuomilehto-Wolf E, Tuomilehto J, Newport MJ, Clayton DG, Todd JA: Comparative highresolution analysis of linkage disequilibrium and tag single nucleotide polymorphisms between populations in the vitamin $D$ receptor gene. Hum Mol Genet 2004, 13:1633-1639.

15. Uitterlinden AG, Fang Y, Van Meurs JB, Pols HA, Van Leeuwen JP: Genetics and biology of vitamin D receptor polymorphisms. Gene 2004, 338:143-156.

16. Hutchinson PE, Osborne JE, Lear JT, Smith AG, Bowers PW, Morris PN, Jones PW, York C, Strange RC, Fryer AA: Vitamin D receptor polymorphisms are associated with altered prognosis in patients with malignant melanoma. Clin Cancer Res 2000, 6:498-504.

17. Halsall JA, Osborne JE, Potter L, Pringle JH, Hutchinson PE: A novel polymorphism in the $1 \mathrm{~A}$ promoter region of the vitamin $\mathrm{D}$ receptor is associated with altered susceptibilty and prognosis in malignant melanoma. Br J Cancer 2004, 91:765-770.

18. Santonocito C, Capizzi R, Concolino P, Lavieri MM, Paradisi A, Gentileschi S, Torti E, Rutella S, Rocchetti S, Di Carlo A, Di Stasio E, Ameglio F, Zuppi C, Capoluongo E: Association between cutaneous melanoma, breslow thickness and vitamin D receptor Bsml polymorphism. Br J Dermatol 2007, 156:277-282.

19. Gapska P, Scott RJ, Serrano-Fernandez P, Mirecka A, Rassoud I, Górski B, Cybulski C, Huzarski T, Byrski T, Nagay L, Maleszka R, Sulikowski M, Lubinski J, Debniak T: Vitamin D receptor variants and the malignant melanoma risk: a population-based study. Cancer Epidemiol 2009, 33:103-107.

20. Li C, Liu Z, Wang LE, Gershenwald JE, Lee JE, Prieto VG, Duvic M, Grimm EA, Wei Q: Haplotype and genotypes of the VDR gene and cutaneous melanoma risk in non-Hispanic whites in Texas: a case-control study. Int $J$ Cancer 2008, 122:2077-2084.

21. Randerson-Moor JA, Taylor JC, Elliott F, Chang YM, Beswick S, Kukalizch K, Affleck P, Leake S, Haynes S, Karpavicius B, Marsden J, Gerry E, Bale L, Bertram C, Field H, Barth JH, Silva Idos S, Swerdlow A, Kanetsky PA, Barrett 
$J H$, Bishop DT, Bishop JA: Vitamin D receptor gene polymorphisms, serum 25-hydroxyvitamin D levels, and melanoma: UK case-control comparisons and a meta-analysis of published VDR data. Eur J Cancer 2009, 45:3271-3281.

22. Mocellin S, Nitti D: Vitamin D receptor polymorphisms and the risk of cutaneous melanoma: a systematic review and meta-analysis. Cancer 2008, 113:2398-2407.

23. Gandini S, Raimondi S, Gnagnarella P, Dore JF, Maisonneuve P, Testori A: Vitamin D and skin cancer: a meta-analysis. Eur J Cancer 2009, 45:634-641.

24. Orlow I, Roy P, Reiner AS, Yoo S, Patel H, Paine S, Armstrong BK, Kricker A, Marrett LD, Millikan RC, Thomas NE, Gruber SB, Anton-Culver H, Rosso S, Gallagher RP, Dwyer T, Kanetsky PA, Busam K, From L, Begg CB, Berwick M, GEM Study Group: Vitamin D receptor polymorphisms in patients with cutaneous melanoma. Int J Cancer 2012, 130:405-418.

25. Chang YM, Newton-Bishop JA, Bishop DT, Armstrong BK, Bataille V, Bergman W, Berwick M, Bracci PM, Elwood JM, Ernstoff MS, Green AC, Gruis NA, Holly EA, Ingvar C, Kanetsky PA, Karagas MR, Le Marchand L, Mackie RM, Olsson H, Østerlind A, Rebbeck TR, Reich K, Sasieni P, Siskind V, Swerdlow AJ, Titus-Ernstoff L, Zens MS, Ziegler A, Barrett JH: A pooled analysis of melanocytic nevus phenotype and the risk of cutaneous melanoma at different latitudes. Int J Cancer 2009, 124:420-428.

26. Gandini S, Sera F, Cattaruzza MS, Pasquini P, Abeni D, Boyle P, Melchi CF: Meta-analysis of risk factors for cutaneous melanoma: I. Common and atypical naevi. Eur J Cancer 2005, 41:28-44.

27. Bishop DT, Demenais F, lles MM, Harland M, Taylor JC, Corda E, RandersonMoor J, Aitken JF, Avril MF, Azizi E, Bakker B, Bianchi-Scarrà G, Bressac-de Paillerets B, Calista D, Cannon-Albright LA, Chin-A-Woeng T, Debniak T, Galore-Haskel G, Ghiorzo P, Gut I, Hansson J, Hocevar M, Höiom V, Hopper JL, Ingvar C, Kanetsky PA, Kefford RF, Landi MT, Lang J, Lubiński J, et al: Genome-wide association study identifies three loci associated with melanoma risk. Nature Genet 2009, 41:920-925.

28. Falchi M, Bataille V, Hayward NK, Duffy DL, Bishop JA, Pastinen T, Cervino A, Zhao ZZ, Deloukas P, Soranzo N, Elder DE, Barrett JH, Martin NG, Bishop DT, Montgomery GW, Spector TD: Genome-wide association study identifies variants at 9 p21 and 22q13 associated with development of cutaneous nevi. Nature Genet 2009, 41:915-919.

29. Barroso E, Fernandez LP, Milne RL, Pita G, Sendagorta E, Floristan U, Feito M, Aviles JA, Martin-Gonzalez M, Arias Jl, Zamora P, Blanco M, Lazaro P, Benitez J, Ribas G: Genetic analysis of the vitamin D receptor Gene in two epithelial cancers: melanoma and breast cancer case-control studies. BMC Cancer 2008, 8:385.

30. Aguilera P, Puig S, Guilabert A, Julia M, Romero D, Vicente A, Gonzalez Ensenat MA, Malvehy J: Prevalence study of nevi in children from Barcelona. Dermoscopy, constitutional and environmental factors. Dermatology 2009, 218:203-214.

31. Ersfeld DL, Rao DS, Body JJ, Sackrison JL Jr, Miller AB, Parikh N, Eskridge TL, Polinske A, Olson GT, MacFarlane GD: Analytical and clinical validation of the $25 \mathrm{OH}$ vitamin D assay for the LIAISON automated analyzer. Clin Biochem 2004, 37:867-874.

32. de Bakker PI, Yelensky R, Pe'er I, Gabriel SB, Daly MJ, Altshuler D: Efficiency and power in genetic association studies. Nature Genet 2005, 37:1217-1223.

33. Gonzalez JR, Armengol L, Sole X, Guino E, Mercader JM, Estivill X, Moreno V: SNPassoc: an $\mathrm{R}$ package to perform whole genome association studies. Bioinformatics 2007, 23:644-645.

34. Lips P: Vitamin D physiology. Prog Biophys Mol Biol 2006, 92:4-8.

35. Guerrieri-Gonzaga A, Gandini S: Vitamin D and overall mortality. Pigment Cell Melanoma Res 2013, 26:16-28.

36. Norman AW, Bouillon R, Whiting SJ, Vieth R, Lips P: $13^{\text {th }}$ Workshop consensus for vitamin D nutritional guidelines. J Steroid Biochem Mol Biol 2007, 103:204-5.

37. Ross AC, Manson JE, Abrams SA, Aloia JF, Brannon PM, Clinton SK, DurazoArvizu RA, Gallagher JC, Gallo RL, Jones G, Kovacs CS, Mayne ST, Rosen CJ, Shapses SA: The 2011 report on dietary reference intakes for calcium and vitamin D from the institute of medicine: what clinicians need to know. $J$ Clin Endocrinol Metab 2011, 96:53-8.

38. Zittermann A, lodice S, Pilz S, Grant WB, Bagnardi V, Gandini S: Vitamin D deficiency and mortality risk in the general population: a meta-analysis of prospective cohort studies. Am J Clin Nutr 2012, 95:91-100.

39. Ovesen L, Andersen R, Jakobsen J: Geographical differences in vitamin D status, with particular reference to European countries. Proc Nutr Soc 2003, 62:813-821.
40. Vaqueiro M, Bare ML, Anton E, Andreu E, Gimeno C, Group DA: Evaluation assessment of the cut-off point of vitamin $D$ in the population older than 64 years old. Med Clin (Barc) 2006, 127:648-650.

41. Mata-Granados JM, Luque de Castro MD, Quesada Gomez JM: Inappropriate serum levels of retinol, alpha-tocopherol, 25 hydroxyvitamin D3 and 24,25 dihydroxyvitamin D3 levels in healthy Spanish adults: simultaneous assessment by HPLC. Clin Biochem 2008, 41:676-680.

42. Calatayud M, Jodar E, Sanchez R, Guadalix S, Hawkins F: Prevalence of deficient and insufficient vitamin $D$ levels in a young healthy population. Endocrinol Nutr 2009, 56:164-169.

43. González-Molero I, Morcillo S, Valdés S, Pérez-Valero V, Botas P, Delgado E, Hernández D, Olveira G, Rojo G, Gutierrez-Repiso C, Rubio-Martín E, Menéndez E, Soriguer F: Vitamin D deficiency in Spain: a populationbased cohort study. Eur J Clin Nutr 2011, 65:321-328.

44. Newton-Bishop JA, Chang YM, Elliott F, Chan M, Leake S, Karpavicius B, Haynes S, Fitzgibbon E, Kukalizch K, Randerson-Moor J, Elder DE, Bishop DT, Barrett JH: Relationship between sun exposure and melanoma risk for tumours in different body sites in a large case-control study in a temperate climate. Eur J Cancer 2011, 47:732-741.

45. Davies JR, Chang YM, Snowden H, Chan M, Leake S, Karpavicius B, Haynes S, Kukalizch K, Randerson-Moor J, Elliott F, Barth J, Kanetsky PA, Harland M, Bishop DT, Barrett JH, Newton-Bishop JA: The determinants of serum vitamin D levels in participants in a melanoma case-control study living in a temperate climate. Cancer Causes Control 2011, 22:1471-1482.

46. Malvy DJ, Guinot C, Preziosi P, Galan P, Chapuy MC, Maamer M, Arnaud S, Meunier PJ, Hercberg S, Tschachler E: Relationship between vitamin D status and skin phototype in general adult population. Photochem Photobiol 2000, 71:466-469.

47. Glass D, Lens M, Swaminathan R, Spector TD, Bataille V: Pigmentation and vitamin D metabolism in Caucasians: low vitamin D serum levels in fair skin types in the UK. PLOS One 2009, 4:e6477.

48. Springbett $P$, Buglass $S$, Young AR: Photoprotection and vitamin D status. J Photochem Photobiol B 2010, 101:160-168.

49. Berwick M: The good, the bad, and the ugly of sunscreens. Clin Pharmacol Ther 2011, 89:31-33.

50. Kiel DP, Demissie S, Dupuis J, Lunetta KL, Murabito JM, Karasik D: Genomewide association with bone mass and geometry in the Framingham heart study. BMC Med Genet 2007, 8(Suppl 1):S14.

51. Karami S, Brennan P, Rosenberg PS, Navratilova M, Mates D, Zaridze D, Janout V, Kollarova H, Bencko V, Matveev V, Szeszenia-Dabrowska N, Holcatova I, Yeager M, Chanock S, Menashe I, Rothman N, Chow WH, Boffetta P, Moore LE: Analysis of SNPs and haplotypes in vitamin D pathway genes and renal cancer risk. PLoS One 2009, 4:e7013.

52. Bonilla C, Hooker S, Mason T, Bock CH, Kittles RA: Prostate cancer susceptibility loci identified on chromosome 12 in African Americans. PLoS One 2011, 6:e16044.

53. Carling T, Rastad J, Akerstrom G, Westin G: Vitamin D receptor (VDR) and parathyroid hormone messenger ribonucleic acid levels correspond to polymorphic VDR alleles in human parathyroid tumors. J Clin Endocrinol Metab 1998, 83:2255-2259.

54. Millikan RC, Hummer A, Begg C, Player J, de Cotret AR, Winkel S, Mohrenweiser H, Thomas N, Armstrong B, Kricker A, Marrett LD, Gruber SB, Culver HA, Zanetti R, Gallagher RP, Dwyer T, Rebbeck TR, Busam K, From L, Mujumdar $U$, Berwick M: Polymorphisms in nucleotide excision repair genes and risk of multiple primary melanoma: the genes environment and melanoma study. Carcinogenesis 2006, 27:610-618.

doi:10.1186/1471-2350-14-26

Cite this article as: Ogbah et al:: Serum 25-hydroxyvitamin D3 levels and vitamin $D$ receptor variants in melanoma patients from the Mediterranean area of Barcelona. BMC Medical Genetics 2013 14:26. 